\title{
The Use of Metatarsal Bone Grafts in the Treatment of Saddle Nose Deformities
}

\section{Ilteris M. Emsen}

Published online: 7 July 2009

(c) Springer Science+Business Media, LLC and International Society of Aesthetic Plastic Surgery 2009

Retraction to: Aesth Plast Surg (2006) 30:705-707 DOI 10.1007/s00266-006-0062-3

This article was retracted by the Editor-in-Chief as portions of it were originally published by B. Neu, Segmental Bone and Cartilage Reconstruction of Major Nasal Dorsal Defects. Plastic and Reconstructive Surgery, Volume 106, Number 1, July 2000, pp. 160-170.

The online version of the original article can be found under doi:10.1007/s00266-006-0062-3.

I. M. Emsen

Department of Plastic and Reconstructive Surgery,

Numune State Hospital, Erzurum, Turkey

I. M. Emsen $(\bowtie)$

Ataturk Universitesi Lojmanlari, 4. Blok, No. 30.,

25240 Erzurum, Turkey

e-mail: ilterisemsen@hotmail.com 